\title{
Political discourse as practical reasoning: A case study of a British Prime Minister candidate speech
}

\author{
Lucyna Harmon \\ University of Rzeszów, Poland
}

\begin{abstract}
The paper outlines the method of political discourse analysis proposed by I. Fairclough \& N. Fairclough (2012), who point to argumentative and deliberative nature of political discourse as practical reasoning that aims to decide a problem-solving action in a given situation. The novelty of this approach is explained through references to its established alternatives as focused on representation and power relations. The above mentioned method is applied to the British PM campaign candidacy speech by Andrea Leadsom to test how it works in the case of this type of political discourse which is different from the one originally examined. On this occasion, the meaning of the term 'discourse' is illustrated through the practical necessity of involving in the analyses the extra-linguistic and intertextual context.
\end{abstract}

Keywords: discourse, politics, deliberation, argumentation, Fairclough

\section{The Notion of Discourse}

It is not easy to determine the meaning of the term discourse in comparison to text, especially as there is a plethora of academic works with discourse in the title that actually offer analyses of selected texts. The decisive point is that the respective texts are then not being examined in isolation but always in context (both extra-linguistic and intertextual), as materialization and manifestation of a certain discourse. This, at least, can be derived from some relevant descriptions of discourse. I intentionally say 'descriptions', rather than 'definitions' since the attempts to explain the notion seem to capture some of its aspects, without being precise enough to pass for a definition. Some examples will be discussed below.

Purvis \& Hunt (1993) qualify discourse as a platform of interaction, where the awareness of socially relevant issues are created, promoted and maintained: 
'discourse' has gained much significance linguistically in modern social theory 'by providing a term with which to grasp the way in which language and other forms of social semiotics not merely convey social experience but play some major part in constituting social objects (the subjectivities and their associated identities), their relations and the field in which they exist'. (p. 474)

As representatives of Critical Discourse Studies (CDS) ${ }^{1}$, Fairclough and Wodak (1997) point to the implications and social consequences of discourse, especially to the relation between the latter and power:

\begin{abstract}
CDS see discourse - language use in speech and writing - as a form of 'social practice'. Describing discourse as social practice implies a dialectical relationship between a particular discursive event and the situation(s), institution(s) and social structure(s), which frame it: The discursive event is shaped by them, but it also shapes them. That is, discourse is socially constitutive as well as socially conditioned - it constitutes situations, objects of knowledge, and the social identities of and relationships between people and groups of people. It is constitutive both in the sense that it helps to sustain and reproduce the social status quo, and in the sense that it contributes to transforming it. Since discourse is so socially consequential, it gives rise to important issues of power. Discursive practices may have major ideological effects - that is, they can help produce and reproduce unequal power relations between (for instance) social classes, women and men, and ethnic/cultural majorities and minorities through the ways in which they represent things and position people. (p. 258)
\end{abstract}

Chilton (2004, p. 4) puts discourse in connection with institutions and points to the essential correspondence between the latter and the former. However, a hesitation occurs when it comes to a clear distinction between discourse and text:

What is strikingly absent from conventional studies of politics is attention to the fact that the micro-level behaviours (...) are actually kinds of linguistic action - that is, discourse. Equally, the macro-level institutions are types of discourse with specific characteristics - for example, parliamentary debates, broadcast interviews. And constitutions and laws are also discourse written discourse, or text, of a highly specific type. (p. 4, emphasis added)

A distinction between discourse and text is attempted by Lemke (1995):

When I speak about discourse in general, I will usually mean the social activity of making meanings with language and other symbolic systems in some particular kind of situation or setting... On each occasion when a particular meaning characteristic of these discourses is being made, a specific text is produced. Discourses, as social actions more or less governed by social habits, produce texts that will in some ways be alike in their meanings... When we want to focus on the specifics of an event or occasion, we speak of the text; when we want to

1 The name was introduced by van Dijk (2009, p. 62), to cover research into discourse and replace the previous label of the latter, namely Critical Discourse Analysis (CDA) in order to avoid its wrong understanding as a method. 
look at patterns, commonality, relationships that embrace different texts and occasions, we can speak of discourses. (p.7)

The above description defines discourse as a generic abstract entity, whilst text is understood as its manifestation and concretization. In this study, discourse is understood as the totality of texts produced in a particular field, within a certain period of time that are linked by a comprehensible criterion like topic, occasion or person. Therefore, an individual text should be considered as a contribution to and an element of the super-ordinated discourse that is sustained by existing and incoming texts. Consequently, it is justified to recognize an analysis of a single text as discourse analysis, as long as the analysis is linked to its intertextual and situational context.

\section{The Essence of Political Discourse}

In order to delimitate political discourse, the notion of politics is usually scrutinized, with the aim to narrow the pool of text producers and/or text production circumstances to be taken into account or ignored in research. The field of politics can be understood quite restrictively, so that it covers solely the activities of professional politicians, or very flexibly, so that it includes ventures of ordinary citizens. Accordingly, political discourse will be comprehended in a narrow or a broad sense, as a set of utterances by politicians only or all possible speakers/writers respectively. In the words of van Dijk (1997, p. 13),

\footnotetext{
as actors and authors of political discourse and other political practices, politicians are not the only participants in the domain of politics. From the interactional point of view of discourse analysis, we therefore should also include the various recipients in political communicative events, such as the public, the people, citizens, the 'masses', and other groups or categories.
}

The British prime minister's candidate speech that will be presented below belongs to the core of political discourse with no doubt: It can be found as such in the established typology by Reisigl \& Wodak (2001, p. 91), where "a speech in election campaign" is listed as "a genre in the field of politics." Therefore, it is not necessary to discuss the selection of the material to be analyzed here. But for the comprehension of the concept of political discourse by Fairclough \& Fairclough it is crucial to understand their view of politics, in contrast to its more established comprehension in relation to power. The scholars maintain that "in politics they primarily engage in argumentation, and particularly in practical argumentation, including deliberation" (2012, p. 4), which differs from the approaches that see it primarily in relation to power. In their opinion,

[p]olitics is about arriving cooperatively and through some form of (collective) argumentation (deliberation) at decisions on actions on matters of common concern, it is about what to do in response to public disagreement and conflict (e.g. over such issues as the distribution of scarce social goods) and in response to circumstances and events. (ibidem, p. 34) 
As mentioned above, politics is often defined in connection to power, in terms of executing it, desiring it, fighting for it etc. In the consequence, the constituent of political discourse as such, namely a political text, is necessarily related to power, too, either as its reinforcement or challenge. For example, van Dijk (2001, p. 359) speaks of "the role of political discourse in the enactment, reproduction and legitimation of power and domination". The structures of a political text serve the purpose of manipulation through selected techniques, like categorization, self-glorification, populism, consensus, number game or victimization (van Dijk 2006, pp. 735739) ${ }^{2}$. They are uncovered, examined and described within Critical Discourse Studies.

As pointed out by Wodak \& Mayer (2001, p. 9), "[t]ypically CDS researchers are interested in the way discourse (re)produces social domination, that is mainly understood as power abuse of one group over others, and how dominated groups may discursively resist such abuse", which confirms the power-connected view of politics.

As illustrated by van Dijk's in his well-known ideological square (2006, p. 734), the typical (or universal) manipulation strategies in the political discourse are the "self positiverepresentation" and "other negative-representation" that the text producers use in order to magnify what is favorable to them (their own achievements and strong points, the opponent's mistakes and weaknesses) and play down what is inconvenient (the opponent's achievements and strong points, the own mistakes and weak points). Therefore, it is understandable that, in research, close attention is paid to representation as the way the text producers present reality, according to their own views, ideologies and purposes. For example, in his parallel analyses of the speeches by US president Bush on the one hand and Osama bin Laden on the other hand, both held in response to the terrorist attack the World Trade Center on 11.09.2001, Chilton (2004) reveals very similar features in the both texts that offer radically different representations of facts, each of them in a manner that favors the respective speaker's needs (pp. 173-193). The focus is on the way in which the orators depict the situation in order to prove the own righteousness and the opponent's evilness.

To sum up: In the traditional approach, political discourse is seen in a strong connection to power as the essence of politics. It is examined, in the first place, for representation of reality that includes intended manipulative twists that should be revealed through critical analysis.

The fact that political speech as a part of political discourse has always been the scholars' and journalists' favorite subject of interest and investigation (Wodak 2005, p. 577) ${ }^{3}$ does not need much explanation. A political speech usually concerns questions of common (local or general) interest and is meant for a broad audience. For the embedment of a political speech, Bitzer (1968) defines the term rhetorical situation that covers "a complex of persons, events objects and relations presenting an actual or potential exigence which can be completely or partially removed if discourse, introduced into the situation, can so constrain human decision or action as to bring about the significant modification of the exigence" (p. 6). In other words,

2 Van Dijk (2006, pp. 735-739) discusses a variety of such techniques. Apart from those mentioned above, some of them are vagueness of meaning, normal expression, polarization, (us-them categorization), counterfactuals, evidentiality, irony, hyperbole and presupposition.

3 An infinite number of such analyses can be retrieved from websites on entering a well-known politician's name followed by the phrase 'speech analysis'. 
a political speech is built upon an exigence as a situation that is "marked by a sense of urgency" (p. 7) and needs action in order to be solved. This perception of the essence of political speech is worth remembering for it seems to fit in with the concept by Fairclough \& Fairclough since it is in agreement with what they call "circumstances", which serves as the point of departure for further reasoning, argumentation and (finally) deliberation.

\section{The Structure of Practical Reasoning by I. Fairclough \& N. Fairclough}

The scholars regard political discourse as practical reasoning that they define as "reasoning about what to do" (Fairclough \& Fairclough 2012, p. 36). It is based on certain values, pursues a goal and calls for an action that should help achieve it. They propose a structure of practical reasoning, and, in the consequence of political discourse, the basic version of which looks like this (Fairclough \& Fairclough 2012, p. 45):

\section{Claim for action $\mathrm{A}$}

(what should be done)

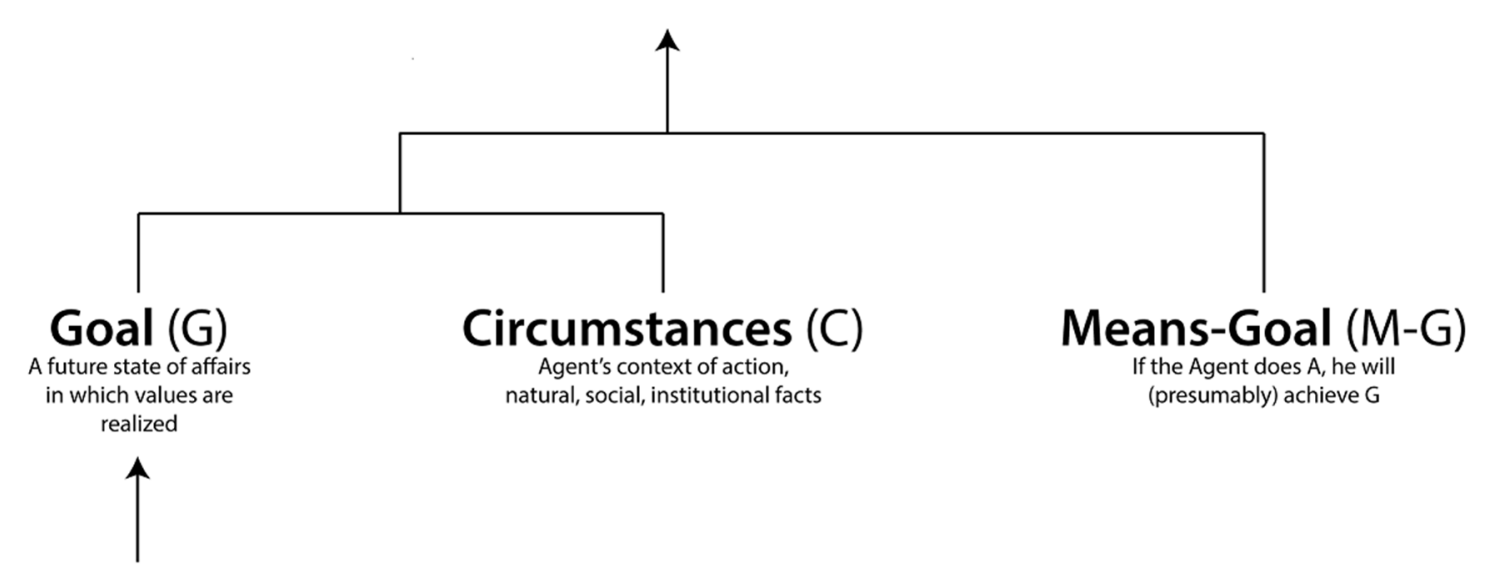

Value (V) - what the Agent is actually concerned with or ought to be concerned with

As mentioned before, in their view, political discourse is "fundamentally argumentative and deliberative" (p. 14), which results from the essence of politics as decision making. The argumentative character requires delivery and defense of plausible arguments that speak for the proposed action (in given circumstances and with appropriate goals as premises). The deliberative nature presumes that "minimally, deliberation involves considering a counterargument, i.e. looking at reasons that support the claim that the action should not be performed" (p.11). Importantly, when elaborating their argumentative-deliberative concept of political discourse, Fairclough \& Fairclough refer to both single-agent and multi-agent discourse (in brief: one speaker or many speakers on the same topic). This allows looking beyond a single text in search for elements of argumentation and deliberation in the examined discourse and confirms the notion of discourse adapted here. 


\section{Purpose and Method of this Study}

My intention is to check if the method proposed by Fairclough \& Fairclough works in the case of a candidacy speech. In their book, the scholars applied it to parliamentary debates carried out directly before a "yes or no" vote in the Parliament. Certainly, a candidacy speech sets a scene for voting, too, but there are at least two vital differences. Firstly, a candidacy speech is bound to be scrutinized, challenged and attacked by adversaries over the whole campaign time (with only limited time for criticism in the case of a parliament speech). Secondly, in the case of elections, voting is based on multiple choice, which means competition/fight whereas a bill, if not accepted, is rejected without immediate acceptance of an alternative. Moreover, like in the example discussed here, a candidacy speech is often held by an "outsider", which may have impact on the design of the text.

I shall examine the speech, paragraph by paragraph, and look for the contents to match the elements of the model in question, i.e. (a) values, (b) circumstances, (c) goal, (d) means-goal relation and (e) call for action. The concordance between the revealed structures of the speech and this particular model will be verified in this way. It goes without saying that, in the case of any candidacy speech, a call for action is inscribed in the external context and is always the same, namely: Support my candidacy, whoever you are and whoever I am.

Through the abovementioned verification of the concordance with the structure of practical reasoning, the (assumed) argumentative and deliberative character of the speech in question will be examined. My hypothesis, based on my personal recipient's experience with candidacy speeches is that the argumentative character of the text to be analyzed can be proved easily, whereas elements of deliberation have to be sought beyond this particular speech, in other texts belonging to the same discourse.

It is important to accept and remember, though, that text/discourse analysis requires interpretation as its inevitable component. This implies that it can always be questioned and confronted with another analysis leading to different conclusions.

\section{External Context: British Prime Minister Campaign 2016}

In the Brexit referendum held on $23^{\text {rd }}$ June 2016, the majority of British people chose to leave the European Union. Due to this result, David Cameron, who strongly supported the "Remain" campaign, announced his resignation as the Conservative Party Leader and Prime Minister, which meant the necessity to start the legal procedure of appointing his successor. Five candidates decided to run for the office, three men (Liam Fox, Stephen Crabb and Michael Gove) and two women (Andrea Leadsom and Theresa May). It was the both ladies who made it to the final stage. The text analyzed below is Leadsom's launch speech held on 4.07.2016. Since enough attention has been and surely will be paid in future to the speeches of Theresa May who, as is well known now, finally became Britain's prime minister, I shall focus on the candidacy speech by Andrea Leadsom who was then an internationally unknown politician and unexpected candidate. In her position of the Junior Energy Minister in Cameron's government she was not even a member of the cabinet (that gathers the prime minister's consultants and advisors). 
A crucial element of the context is Leadsom's strong dedication to and engagement in the successful "Leave" campaign. Another important matter is the fact that a referendum result is legally not binding for the government in the UK. Therefore, although hardly imaginable in the established British democracy, the government still could - in accordance with the law - decide for Britain to remain in the EU.

\section{The analysis of Leadsom's speech ${ }^{4}$}

For the obvious reason of space limitation here, only selected elements of the speech will be discussed. They are supposed to match the structural constituents of practical reasoning, as illustrated through the scheme provided above.

\section{a) Values}

Two big values are strongly accentuated in the initial and the final part of the speech, respectively: freedom ("We are choosing freedom away from the stifling EU institutions") and democracy ("Our democracy is the oldest in the world"). It is pointed out that it is the former that enables the latter. The outcome of a referendum is pictured as a big success that gave back freedom to British people. Thus, the conceptualization offered is that of a war just won against an oppressor. The reference to the fall of the Berlin wall puts additional emphasis to the importance of this factor on the one hand, and to the weight of the yoke dropped on the other hand.

\section{b) Circumstances}

The speaker declares that "the referendum result is final". This seems to be a double message, to reassure the "Leave" supporters that Brexit will be executed for certain, and possibly destroy the hopes of the others. Therefore, the statement obtains the function of a hidden appeal for the union of the British nation (which is later explicitly indicated as a goal).

She states "a division within the nation", with a conciliatory observation that "the referendum didn't cause divisions but it certainly did reveal them", which prevents the qualification of the referendum as the origin of the problem and thus an "evil".

The PM candidate confirms that "many people are shocked at the referendum result", which reinforces the diagnosis of division and underlines that the outcome of the voting was rather surprising. She hurries to appease the disappointed with the assurance that there is no reason for them to be worried: "What I would like to say to them is please: Don't be afraid; We haven't lost our senses; We haven't stopped caring about each other; We haven't stopped loving our families and children; We haven't stopped loving our country either". This sounds, once again, like an appeal for unity.

The speaker realizes that "many citizens are not happy about their economic situation", which serves as a link for her promises to improve the quality of their lives, if elected ("The

\footnotetext{
4 The full text is enclosed in Appendix.
} 
importance of wealth and job creation is core to all my beliefs...", "Workers' rights under my leadership will be protected and enhanced.").

A further step is to point to the guilty of the situation: "The EU elites failed to handle crucial problems". Therefore, the responsibility for the British people's wish to exit EU, is clearly ascribed to the latter. Besides, when saying that "the rich who caused the 2008 crash were not brought to book", Leadsom reveals national negligence and thus room for local vindications.

It should be noted that the presentation of circumstances here can be considered as an "exigence package" in the sense of the above mentioned rhetorical situation by Bicker. The set of conditions as depicted by the speaker justifies the need to respond with measures that are meant as solutions.

c) Goals (desired states of affairs)

The speaker mentions two relevant goals to be pursued by the new government: "bringing the nation together" and "building a greater Britain" (outside EU). The former directly results from the above mentioned diagnosis of the circumstances that include a split society, with strong support for both staying with UE and leaving it. Since the decision about Brexit is considered final, bringing the nation together can only mean convincing the unconvinced about the righteousness of the choice to leave. The latter sounds like as allusive wordplay (since Great Britain is great anyway ${ }^{5}$ it can only be made greater) and a rather extensive slogan, with infinite number of possible specifications.

d) Means that can lead to the goals (M-G)

Only quick Brexit as an initial means and the changes that it enables can make it possible to achieve the goals: "Neither we nor our European friends need prolonged uncertainty and not everything needs to be negotiated before Article 50 is triggered and the exit process is concluded". Brexit will entail that "decisions about Britain will be made in Britain, by the British parliament" (argument for means) so that "billions of pounds more will be invested in the NHS from the savings we make from cancelling our EU membership fee" (argument for means). The EU citizens who are in the UK already should be granted the right to stay (emotional argument for means): "I commit today to immediately guaranteeing the rights of our EU friends who have already come here to live and work. We must give them certainty they will not be bargaining chips in our negotiations".

In order that all the above can happen, as a super-ordinated means to the goals, a guarantor and executor of an effective Brexit as well as the required reforms are needed, namely herself, the speaker Andrea Leadsom with all her skills and abilities. She says: "It was a big decision to put myself forward to lead our country. One that was driven by my absolute conviction that our future, and that of our children and grandchildren, will be so much better outside the EU". The

5 In one of the episodes of "Doctor Who", a very popular British TV series, the main character says that "only Britain is great". 
argument so far is emotional, which does not deprive it of the argument status. A more concrete line of reasoning follows with enumeration of her experience and achievements: "I chaired and founded charities, I care a lot about children" or "I've sat on the Treasury select committee. I've been City minister and Energy minister. I set up and led the Fresh Start Project with the support of over a hundred MPs" (arguments).

\section{e) Call for Action}

As mentioned already, it is clear that the call for action in every election campaign speech, even if not articulated, is always the same and reads: Vote for me. In the Leadsom speech, the arguments for the speaker's candidacy are enumerated and elaborated in the part introduced with the pseudo rhetoric question "Why me?" as a transparent invitation to elect her. She claims to have the right attitude (reflected in her promises and commitments), skills and qualifications.

\section{Resume (a-e)}

The kernel points of reasoning in the Leadsom speech are these: British people appreciate democracy and freedom (values). As long as UK remains EU member, these values cannot be converted (decisions are made in Brussels). The referendum result with its ramifications (circumstances) means a big chance for the British nation to regain democracy and freedom and the people need and want them back (goals). Regarding the difficult economic, political and social conditions (circumstances) the goals pose a big challenge for the new prime minister. The goals can be achieved, though, with Leadsom in this role since she is equipped with the necessary skills, experience and attitude (means-goal), so it is recommendable to entrust her with the leadership (call for action).

\section{Critical Comments}

In the presentation of circumstances, only avoided losses in the new circumstances are put forward (ties to European people as friends and trade partners, national security through NATO membership), immediately followed by criticism of the opposite camp (decision makers of Brussels) as justification of the people's choice (failure to deal properly with youth unemployment, declining share of world trade and globalization).

Unmentioned is the fact that the idea of Brexit attracted only a slight majority of voters (51.9\%), part of them - as argued in the aftermath comments - not being fully aware of the practical consequences. No reference is made to the voices that condemned the referendum result assessment rule.

The comparison to the Berlin Wall, the purpose of which was to stop emigration from Eastern Germany to the West has no substantial foundation and is solely emotional rhetoric. Please note that the mere idea of Brexit draws on the immigration problem, i.e. emigration, from the Eastern European perspective. The fall of the Berlin Wall made migration possible again. Erected in 1961, the wall separated West Berlin from what was ironically referred to as 
"Berlin Capital" and at the same time from the whole Eastern Germany. Once the wall was removed by German people themselves in a collective action of taking it apart brick after brick (1990), the process of democratization was started that included the freedom to move.

A masterpiece (or a cunning trick) underlies the following utterance:

\footnotetext{
The result is final. It must be respected and I will respect it. The United Kingdom will leave the European Union. Freedom of movement will end and the British parliament will decide how many people enter our country each year to live, work and contribute to our national life (emphases added).
}

As can be seen, the initial judgment is formed in Passive Voice, which renders it impersonal and thus objective in character. Then, the sentence in Active Voice starts with the personal "I" so that the following actions are presented as consequences of the speaker's action or attitude (in the prime minister's role).

The abovementioned statement about the referendum result being final is ambiguous. Firstly, because it is legally not biding for the government. Secondly, because with the $51.9 \%$ of Brexit supporters it is not convincing. Many think that a qualified majority should be required for an extremely important decision like EU membership.

In the light of the above observations it seems justified to conclude that the circumstances are presented in a modified version, in an evaluative manner that suits the speaker's purposes. Undoubtedly, the Brexit idea should be reinforced and promoted in this way and the speaker's position as a PM candidate - strengthened.

As regards the speaker's qualifications and experience, they were scrutinized and questioned by journalists. For example, as argued by Oliver Milne in The Sun as well as by Simon Bowers, Holly Watt and Davig Pegg in The Guardian (both from $6^{\text {th }}$ July 2016), she lacks fund managing and team leading experience.

Concerning the timing of Brexit procedures, numerous UK experts and politicians would like to delay the withdrawal process from EU to prepare it carefully, rather than in a hurry. As pointed out by Jamie Micklethwaithe in the Evening Standard on $27^{\text {th }}$ June, the group of supporters of the slow approach includes the then Chancellor Osborne from Leadsom's own party, whom she mentions with admiration: "I'll continue to build on the good work that George Osborne has done in reducing the deficit". This implies that a prime minister like Leadsom, who is determined to act quickly in this respect, may not be the best choice at all.

When promising the current foreign UK residents the right to stay, Leadsom displays her care for people's lives and thus her human face. But she does not provide any rational arguments to support this idea which has strong opponents Britain. To illustrate, as reported by Dan Bloom in The Mirror on $4^{\text {th }}$ July, Theresa May refused to guarantee it and Immigration Minister Brokenshire confirmed her decision as the government's policy. What results from this is that a strong commitment for the foreigners' benefit does not necessarily strengthen Leadsom's position or increase her chances to be elected prime minister. 


\section{Summary and Conclusion}

The candidacy speech by Andrea Leadsom has been examined in order to determine whether its construction matches the structure of practical reasoning proposed by Fairclough \& Fairclough and whether it confirms the argumentative and deliberative character of political discourse as claimed by these scholars. It was shown that the design of the speech corresponds to the structure of practical reasoning. The argumentative character of the discourse can be seen already on the level of the speech itself whereas elements of deliberation have not been encountered in the speech. According to the expectations, they appear only beyond the text by Leadsom, in critical responses to and comments on her address. This finding is compatible with the thesis by Fairclough \& Fairclough about the argumentative and deliberative character of political discourse in general, as long as the notion of discourse covers a multitude of related texts.

\section{References}

Bitzer, L.F. (1968). The Rhetorical Situation. Philosophy and Rhetoric 1, 1-14.

Chilton, P. (2004). Analysing Political Discourse. Theory and Practice. London: Routledge.

Fairclough, I., \& Fairlclough, N. (2012). Political Discourse Analysis: A Method for Advanced Students. London: Routledge.

Fairclough, N., \& Wodak, R. (1997). Critical Discourse Analysis. In T.A. van Dijk (Ed.), Discourse Studies: A Multidisciplinary Introduction 2 (pp. 258-284). London: Sage.

Lemke, J. (1995). Textual Politics: Discourse and Social Dynamics. London: Taylor and Francis.

Purvis, T., \& Hunt, A. (1993). Discourse, ideology, discourse, ideology, discourse, ideology... The British Journal of Sociology 4, 473-499.

Reisigl, M., \& Wodak, R. (2001). Discourse and Discrimination: Rhetoric of Racism and Antisemitism. London: Routledge.

Van Dijk, T.A. (1997). What is Political Discourse Analysis? Retrieved from http://www.discourses.org/OldArticles/Politics,\%20Ideology\%20and\%20Discourse.pdf. 6.09.2016.

Van Dijk, T. A. (2001). Critical Discourse Analysis. In D. Schiffrin, D. Tannen \& H.E. Hamilton (Eds.), The Handbook of Discourse Analysis (pp. 352-37). Blackwell.

Van Dijk, T.A. (2006). Politics, Ideology, and Discourse. Retrieved from http://www.discourses.org/OldArticles/Politics,\%20Ideology\%20and\%20Discourse.pdf. 2.09.2016.

Van Dijk, T.A. (2009). Critical Discourse Studies: A Sociocognitive Approach. In R.Wodak \& M. Meyer (Eds.), Methods for Critical Discourse Analysis (pp. 62-86). London: Sage.

Wodak, R. (2005). Language and Politics. Retrieved from

http://host.uniroma3.it/linguisti/lcs-ingles/Roma3/Newsblog/Entries/2014/4/6_New_class_time_files/Wodak -Language\%20and\%20Politics.pdf. 2.09.2016.

Wodak, R. and Meyer, M. (2001) Critical Discourse Studies: History, Agenda, Theory and Methodology. Retrieved from https://www.corwin.com/sites/default/files/upm-binaries/24615_01_Wodak_Ch_01.pdf. 15.09.2016.

\section{Appendix}

Andrea Leadsom candidacy speech, retrieved from: http://blogs.spectator.co.uk/2016/07/want-guidebritain-sunlit-uplands-full-text-andrea-leadsoms-leadership-speech/ (2.10.2016) 
The decision we took on the 23rd June was a great moment in history. Not just a historic opportunity for our country but for Europe as a whole. Perhaps the biggest moment since the Berlin Wall came down. We are not leaving any of our historic ties with our European friends, We are choosing freedom away from the stifling EU institutions. Through NATO we remain bound through the 1949 treaty to come to the defense of Europe's democracies if they are attacked. The nations and peoples of Europe remain our close friends, staunch allies and key trading partners. I believe, however, that our vote to leave the EU will be a positive wake up call for those European elites who have been far too complacent about:

- Youth unemployment that is wrecking lives in S Europe

- The declining share of world trade that threatens Europe's progress, and

- The failure of the Brussels machine to respond to globalization.

Because of our decision on June 23, we are no longer bound to that EU model. We will have our freedom back. Today I want to talk first about our future place in Europe, second about building a greater Britain and then, third, about why I am the best choice to lead our country forward. I want to start with the result of the referendum and the clear choice of the British people. The result is final. It must be respected and I will respect it. The United Kingdom will leave the European Union. Freedom of movement will end and the British parliament will decide how many people enter our country each year to live, work and contribute to our national life. Billions of pounds more will be invested in the NHS from the savings we make from cancelling our EU membership fee. The laws and regulations that govern the British people will be made in Britain - and not Brussels. And at elections the British people will be able to appoint or sack politicians, secure in the knowledge that EU bureaucracy cannot undermine their wishes. I intend to keep the negotiations as short as possible. Neither we nor our European friends need prolonged uncertainty and not everything needs to be negotiated before Article 50 is triggered and the exit process is concluded. My team will set out trade, border and security agreements - our renegotiation will be in the hands of a dedicated Cabinet colleague. I emphasise 'dedicated'. The team that I will assemble to lead Britain out of the EU will consult opposition politicians, business people, farmers, trades unions and trade negotiators. I will closely consult with colleagues from the Scottish, Welsh and Northern Irish devolved parliaments, as well as here in Westminster, to make the most of the huge opportunity that lies ahead. I will do everything in my power to keep the United Kingdom United.

And this brings me on to my second of three themes for today. The next prime minister must bring the nation together. The EU referendum didn't cause divisions but it certainly did reveal them. Many people are shocked at the result but they really shouldn't be. What I would like to say to them is please: Don't be afraid; We haven't lost our senses; We haven't stopped caring about each other; We haven't stopped loving our families and children; We haven't stopped loving our country either; We've just rediscovered our Freedom!

It's very obvious that many fellow citizens are unhappy with the way the economy works for them. So it won't be enough to protect the working people of this country by just reducing the flow of low-skilled labour - although that is necessary. When there is room for tax cuts they must be focused on the low-paid. The importance of wealth and job creation is core to all my beliefs but the richest people of Britain should know that they will not be my priority. Britain will make her way in the world by investing in the skills of her people - not by expecting them to adopt unacceptable conditions. And those people who have become rich by winning boardroom pay rises that bear no relation to company performance should be aware that I find this unacceptable. Too few people in my old field of financial services were ever brought to book for their part in the 2008 crash.

I'll continue to build on the good work that George Osborne has done in reducing the deficit. We have to get our house in order. The Chancellor's sound northern powerhouse project needs to be supercharged, and I won't forget that Sunderland was one of the first to make very clear, last Friday morning, the desire for change. I will appoint a key minister for housing and try my hardest to keep him or her in the job for the rest of the parliament. I want a minister who thinks of nothing other than how to use a bigger housing budget to deliver on the aspirations of the working people of this country. As well as spending more on roads, railways and broadband I'll make rapid decisions on airport expansion. Business needs certainty. I will prioritise new trade deals with the fastest growing parts of the world, a simpler tax system, and an immigration policy focused on bringing the most talented people to our country. Workers' rights under my leadership will be protected and enhanced, as my friend Gisela Stuart MP and I made clear during the referendum debates. The national living wage, the apprenticeship levy and Michael Gove's important pupil premium will all be safe under my watch. And I commit today to immediately guaranteeing 
the rights of our EU friends who have already come here to live and work. We must give them certainty - they will not be bargaining chips in our negotiations.

Finally, why me? It was a big decision to put myself forward to lead our country. One that was driven by my absolute conviction that our future, and that of our children and grandchildren, will be so much better outside the EU. But my real passion in politics is my desire for social justice - for a transformation of our society. For nearly two decades I've been chairing and founding new charities to support the earliest years of life. There is no doubt that the period from conception to the age of two is critical...it is during this period that the lifelong emotional capacity of a human being is largely set up. Being able to learn, being able to make friendships, to hold down a job, to have a sense of self-worth. These sound very basic, but for too many in our country these things are elusive. And there's a financial angle to this. The choice our country faces is simple: We spend more on early intervention or we spend much more later on picking up the pieces of lives that struggled at school, struggled in work, and all too often found themselves without hope. I am certain we can change that, and my absolute commitment to it and the emotional health of our nation.

So, what else have I done? I've been in business for 25 years, running businesses large and small and working in charities. I know from long experience how our economy works. I know how to strike a deal in a tough negotiation. I know, as a woman, how to succeed in a man's world and how to fight the unfortunate prejudice that many working mums experience. I've sat on the Treasury select committee. I've been City minister and Energy minister. I set up and led the Fresh Start Project with the support of over a hundred MPs. Together we oversaw the biggest ever investigation into EU laws that any parliamentary group has ever undertaken. Through that Group, I am better prepared for the coming negotiations than anyone else. I know I can do the job. I know I can seize the great opportunities for the UK in leaving the EU, and I am confident I can do it in a way that reaches out to those who didn't vote for it. I know I can deliver more fairness for people who have struggled to make their way. Finally, I want to make an appeal to the country. Our democracy is the oldest in the world. We are the mother of all parliaments. We have led the world in human rights. Let's show the world that we can disagree. We can disagree strongly, but let's also show them that we treat each other with respect. I believe this nation can become the greatest on earth. Our future is not written until we, the people, write it. As your prime minister my ambition will be to guide our country to the sunlit uplands - a future for our children and grandchildren of aspiration, tolerance and hope. 